\title{
MEMBANGUN KEPUASAN KONSUMEN PROPERTY MELALUI HARGA BERSAING DAN KUALITAS PELAYANAN PADA PERUMAHAN PT. ATLANTIK PERKASA ABADI PEKANBARU
}

\author{
Wirdayani Wahab \\ Program Studi Manajemen STIE Mahaputra Riau \\ Jl.Paus, Pekanbaru \\ E-mail: wirdayaniwahab@yahoo.com \\ diterima: 2/4/2019; direvisi: 24/5/2019; diterbitkan: 24/9/2019
}

\begin{abstract}
Consumer satisfaction becomes a target that must be carried out by producers of both goods and services. In the product goods in this case is housing produced by PT. Atlantik Perkasa Abadi Pekanbaru allegedly an effort that can be done by way of price competition and also improving the quality of service. Proof of this allegation was carried out on 52 consumers taken randomly through a questionnaire and the data were analyzed quantitatively by means of multiple linear regression. The results of the research prove that competitive prices and quality services simultaneously and partially have a significant effect on customer satisfaction and it is also proven that competitive prices provide the most dominant influence on consumer satisfaction.
\end{abstract}

Keywords: Price Competition, Service Quality, Property Customer Satisfaction

\section{PENDAHULUAN}

Perumahan menjadi sebuah produk yang saat ini sedang sangat dibutuhkan oleh masyarakat. Khususnya masyarakat perkotaan perumahan menawarkan kemudahan. Tanpa harus mengumpulkan bahan bangunan dan membeli tanah yang urusannya sangat rumit mereka dengan mudah dapat memiliki rumah idaman sesuai dengan kemampuan yang dimiliki.

Selain itu juga di daerah perkotaan untuk mendapatkan fasilitas yang standar tempat tinggal, perumahan memang menjadi pilihan yang baik. Apalagi saat ini pemerintah Indonesia membuat program rumah jokowi, dimana dengan konsep rumah terjangkau di beli masyarakat dan dengan waktu cicilan yang dinilai mampu dijalani oleh masyarakat.

Namun banyaknya persaingan produsen perumahan membuat para pengembang berpikir lebih jauh bagaimana produksi rumah yang dihasilkan dapat dipilih oleh konsumennya. Hal ini memang tidak akan terlepas dari kepuasan konsumen perumahan (property) itu sendiri.

Kepuasan konsumen itu penting dimana dijelaskan menurut Tjiptono (2014) kepuasan yang diberikan produsen kepada konsumennya akan mampu membuat konsumen merekomendasikan pengalaman membeli kepada pihak lain. Selain itu juga banyak hal yang dinilai penting memberikan kepuasan kepada para pelanggannya, seperti dalam rangka membuat pengembang dapat mempertahanklan dan bahkan mengembangkan perusahaannya secara berkesinambungan.

Pengembang (developer) yang saat ini sedang aktif melaksanakan pengembagan property di Pekanbaru adalah PT. Atlantik Perkasa Abadi. Perusahaan ini sudah semenjak lama menekuni bisnis property ini dan banyaknya kebutuhan perumahan menyebabkan perusahaan harus siap membangun proyek-proyek perumahan untuk memenuhi kebutuhan konsumen. 
Jurnal Ilmiah Ekonomi dan Bisnis

Vol. 16. No.2, September 2019: 135-142

EISSN : $2442-9813$

ISSN : $1829-9822$

Selain itu harga yang ditetapkan oleh perusahaan haruslah harga yang tejangkau oleh konsumen, mengingat banyaknya konsumen yang belum mampu untuk membeli rumah secara tunai. Sehingga masyarakat lebih memilih mengontrak rumah daripada harus membeli rumah.

Pada mulanya perusahaan ini melakukan produksi pengembangan property di tahun 2012. Lokasi perusahaan ini berada di jalan Pekanbaru-Bangkinang. Perusahaan membangun rumah dengan berbagai macam type, namun penulis hanya mengambil rumah type 36 untuk diteliti dengan alasan perusahaan membangun rumah dengan type 45 dan type 50 hanya pada tahun 2012, sedangkan data penulis teliti dimulai dari tahun 2013-2107, dimana perusahaan tidak lagi membangun type tersebut.

Berikut ini disajikan harga rumah dan jumlah rumah yang terjual pada PT. Atlantik Perkasa Abadi.

Tabel 1 Daftar Harga Rumah Pada PT. Atlantik Perkasa Abadi Pekanbaru

\begin{tabular}{|c|c|c|}
\hline Tahun & $\begin{array}{c}\text { Type } \\
\text { Rumah }\end{array}$ & Harga Rumah \\
\hline 2013 & Type 36 & Rp. 88.000.000-, \\
\hline 2014 & Type 36 & Rp. 105.000.000-, \\
\hline 2015 & Type 36 & Rp. 110.000.000-, \\
\hline 2016 & Type 36 & Rp. 116.500.000-, \\
\hline 2017 & Type 36 & Rp. 123.000.000-, \\
\hline
\end{tabular}

Sumber: PT. Atlantik Perkasa Abadi Pekanbaru

Dilihat dari tabel 1 harga rumah pada PT. Atlantik Perkasa Abadi Pekanbaru dari tahun 2013 sampai dengan tahun 2017 menunjukkan adanya kenaikan harga setiap tahunnya. Pada tahun 2013 harga rumah pada PT. Atlantik Perkasa Abadi Pekanbaru adalah Rp. 88.000.000-, untuk tahun 2014 harga rumah adalah $\mathrm{Rp}$. 105.000.000-, tahun 2015 harga rumah adalah Rp. 110.000.000-, tahun 2016 harga rumah adalah Rp. 116.500.000-, sedangkan untuk tahun 2017 harga rumah adalah Rp. 123.000.000,-

Tabel 2: Target dan Realisasi Penjualan Rumah Pada PT. Atlantik Perkasa Abadi Pekanbaru

\begin{tabular}{|c|c|c|}
\hline Tahun & Target & Realisasi \\
\hline 2013 & 100 Unit & 75 Unit \\
\hline 2014 & 100 Unit & 94 Unit \\
\hline 2015 & 120 Unit & 101 Unit \\
\hline 2016 & 120 Unit & 85 Unit \\
\hline 2017 & 300 Unit & 110 Unit \\
\hline
\end{tabular}

Sumber: PT. Atlantik Perkasa Abadi Pekanbaru

PT. Atlantik Perkasa Abadi membangun rumah dengan jumlah 600 unit, dan total rumah yang telah terjual dari tahun 2013-2017 adalah 465 unit. Dari tabel 2 dapat diketahui bahwa jumlah rumah yang terjual dalam lima tahun terakhir menigkat dari tahun 2013-2015, yaitu pada tahun 2013 jumlah rumah yang terjual sebanyak 75 unit dengan target penjualan 100 unit, tahun 2014 sebanyak 94 unit dengan target penjualan 100 unit sedangkan untuk tahun 2015 sebanyak 101 unit dengan target penjualan 120 unit. Namun pada tahun 2016 mengalami penurunan yaitu jumlah rumah yang terjual sebanyak 85 unit dengan target penjualan 120 unit. Sedangkan untuk tahun 2017 mengalami kenaikan jumlah rumah yang terjual sebanyak 110 unit dengan target penjualan 300 unit.

Kondisi yang terus mengalami penurunan ini membuat perusahaan terus berpikir bagaimana meningkatkannya. Terutama yang dilakukan dalam rangka meningkatkan kepuasan konsumennya. Selain persoalan tersebut, ternyata banyak fenomena lainnya dinilai yang terjadi pada perusahaan ini, seperti masalah harga yang cenderung kurang bersaing. Kemudian masalah kualitas dari pelayanan yang diberikan kepada konsumen yang cenderung mendapatkan 
berbagai keluhan. Seperti ada beberapa hal yang menjadi keluhan konsumen; 1) persetujuan untuk akad rumah, lama disetujui oleh bank, 2) seringmya berkas-berkas konsumen yang hilang, 3) pembangunan yang tidak sempurna seperti dinding retak, keramik renggang, plafon gipsum yang renggang, cat rumah yang kotor dan lain sebagainya.

Hal ini sebagaimana dijelaskan menurut Daryanto (2014) menjelaskan bahwa dua faktor penting yang dapat dilakukan dalam rangka memuaskan konsumen adalah faktor harga dan faktor layanan.

Jadi dengan kondisi yang demikian, pada naskah mengajukan pertanyaan apakah faktor harga yang bersaing dan juga pelayanan yang berkualitas mampu meningkatkan kepuasan konsumen property.

\section{TINJAUAN PUSTAKA}

Beberapa konsep teori yang digunakan untuk dijadikan landasan dan kajian ini antara lain konsep pemasaran, karena kajian ini merupakan kajian pemasaran khususnya pemasaran barang (property). Menurut Stanton dalam Suhendi (2014), pemasaran menjadi hal penting bagi perusahaan karena pemasaran adalah mata yang melihat kebutuhan konsumen untuk dapat dipenuhi. Hal ini juga sejalan dengan apa yang dikatakan Swastha dan Sukotjo (2010) dan juga Alma (2011).

Sedangkan menurut Abdullah dan Tantri (2014) konsumen potensial akan menjadi fokus pada proses sistem pemasaran, hal serupa dijelaskan oleh Kotler dan Keller (2012).

Dari pendapat tentang pemasaran tersebut, maka dapat dengan jelas bahwa pemasaran merupakan proses memperkenalkan produk dari produsen ke konsumen dalam rangka memenuhi kebutuhan konsmen.

Kepuasan Konsumen
Beberapa ahli berpendapat mengenai kepuasan konsumen yakni bagian penting dari kajian manajemen pemasaran dapat dijelaskan menurut Tjiptono (2014:); Suhendi dan Sasangka (2014); Umar (2005) bahwa kepuasan konsumen merupakan ungkapan rasa puas dari apa yang dirasakan dengan yang diharapkan.

Hal lain pula menurut Sangadji dan Sopiah (2013) kepuasan merupakan perasaan senang atau gembira dari apa yang dinikmati. Jadi dari uraian tersebut dapat dengan jelas dikatakan bahwa kepuasan merupakan perasaan senang atau gembira dari apa yang dirasakan dibandingkan dengan apa yang diharapkan.

Untuk mengukur puas tidaknya konsumen terhadap produk yang dikonsumsi menurut Tjiptono (2014), harapan konsumen; dimensi kepuasan (seperti: kecepatan pelayanan, sarana dan prasarana pelayanan, atau keramahan staf pelayanan kepada konsumen); niat beli ulang; kesediaan untuk merekomendasikan.

Sedangkan menurut Kotler, et al. dalam Tjiptono (2008) terdapat empat metode mengukur kepuasan konsumen antara lain: menyediakan kotak yang berisikan berbagai keluhan konsumen; mengutus mata-mata untuk membeli dan menilai hasil proses pembeliannya; kemudian menilai konsumen yang tidak membeli ulang serta melakukan survei kepada konsumen.

Kemudian juga dapat dijelaskan terdapat banyak faktor determinam kepuasan seperti menurut Daryanto (2014); dan Juwandi (2008), yakni: kualitas produk, harga, kualitas layanan, dan faktor emosional serta biaya dan kemudahan.

Dari uarian tersebut, dapat difokuskan pada faktor yang mempengaruhi utama kepuasan konsumen adalah faktor harga bersaing dan juga 
Jurnal Ilmiah Ekonomi dan Bisnis

Vol. 16. No.2, September 2019: 135-142

EISSN : $2442-9813$

ISSN : $1829-9822$

kualitas pelayanan untuk pemasaran produk perumahan.

Harga Bersaing

Beberapa pendapat yang membahas mengenai konsep harga bersaing sebagaimana dijelaskan oleh Tjiptono (2008); Malau, (2017); Tjiptono dan Chandra (2012); Umar (2005); dijelaskan harga ialah biaya yang dikorbankan konsumen untuk mendapatkan barang atau jasa dari produsen. Kemudian Lupiyoadi (2006) menjelaskan beberapa faktor penentu harga antara lain: harga akhir produksi, penyesuaian harga, dan perbandingan harga.

Sedangkan ukuran harga bersaing itu sendiri menurut Stanton dalam Hasibuan, (2016) yakni: harga terjangkau; kemudian sebanding harga barang dengan kualitas; persaingan harga; perbandingan harga dengan manfaat. Sedangkan Kotler dan Amstrong dalam Hasibuan (2016) menambahkan rincian harga pokok yang bersaing itu dengan menambang discount, potongan harga dan juga cicilan pembayaran.

Kualitas Pelayanan

Kualitas pelayanan dari pendapat Goetcch dan Davis dalam Tjiptono dan Chandra (2011); Wijaya (2011:11); Kotler dalam Sopiah (2013) yakni sebuah situasi produk yang diberikan produsen kepada konsumennya yang melebihi standar yang ditawarkan. Harapan pelanggan menjadi bagian standar yang memang diharapkan.

Sedangkan yang menjadi ukuran dari kualitas pelayanan digunakan pendapat Tjiptono dan Chandra (2012) yakni: reliabilitas; responsivitas; assurance; Empaty serta tangibles.

\section{METODE PENELITIAN}

Penelitian ini dilakukan pada konsumen perumahan di PT. Atlantik
Perkasa Abadi Pekanbaru-Riau yang beralamat di Jl. Pekanbaru-Bangkinang KM.12 (Setelah Pos Polisi) Ruko No.5 Rimbo Panjang.

Yang menjadi populasi yakni konsumen perumahan PT. Atlantik Perkasa Abadi yang berjumlah 110 orang yakni konsumen rumah type 36. Pemilihan populasi merupakan objek pokok dalam penelitian. Sampel diambil sebanyak 52 orang dengan menggunakan pendapat Toro Yamene (Sugiyono, 2010), yakni:

$n=\frac{N}{1+N \cdot d^{2}}$

$$
\text { Ket } \quad \begin{array}{ll}
\mathrm{n} & =\text { sampel } \\
\mathrm{N} & =\text { Populasi } \\
\mathrm{d}^{2} & =10 \%
\end{array}
$$

rinciannya dapat dilihat dari uraian sebagai berikut ini :

$n=\frac{N}{1+N \cdot d^{2}}$

$n=\frac{110}{1+110.0,01}$

$n=\frac{110}{1+1,10}$

$n=\frac{110}{2,10}$

$\mathrm{n}=52$

Sedangkan teknik pengambilan sampel yang digunakan yakni menggunakan cara random sampling. Data dikumpulkan dengan menggunakan kuesioner dan dianalisis dengan teknik analisis kuantitatif. Alat analisis dengan regresi linier berganda. Sebelumnya dilakukan uji validitas dan juga uji reliabilitas Nyoto (2015); juga dilakukan analisis asumsi klasik dan normalitas data. Analisis data menggunakan teknik multiple regression. 


\section{Pengujian Hipotesis}

$$
\text { ISSN : } 1829-9822
$$

\section{HASIL DAN PEMBAHASAN}

Dari hasil ujicoba kuesioner dengan menggunakan kelayakan dan hasilnya layak dengan nilai kelayakan parsial diatas 0,300 dan untuk simultan lebih besar dari 0,600. Serta dari hasil perhitungan asumsi klasik semua variabel bebas dari asumsi klasik. Selanjutnya dari uji normalitas dapat diketahui data dalam kondisi normal.

Berdasarkan hasil analisis regari yang dilakukan yang terlihat pada tabel berikut:

Tabel 3: Output

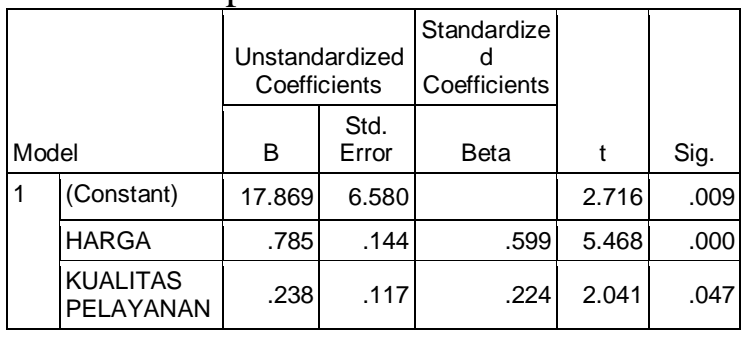

Formula hasil penelitian yang dihasilkan sebagai berikut:

$Y=17,869+0,785 x_{1}+0,238 x_{2}+e$

Analisisnya :

a. Konstanta (a) bernilai 17,869 jika variabel harga dan kualitas pelayanan sama dengan nol, maka kepuasan konsumen (Y) diperoleh 17,869 .

b. Nilai koefisien regresi dari variabel harga 0,785 artinya jika variabel kepuasan konsumen naik 1 satuan maka variabel kepuasan konsumen akan mengalami kenaikan 0,785 .

c. Nilai koefisien regresi kualitas pelayanan 0,238 artinya jika variabel kepuasan konsumen naik 1 satuan maka variabel kepuasan konsumen akan mengalami kenaikan 0,238.
Hasil uji yang dilakukan untuk membuktikan dugaan dengan perhitungan sebagai berikut:

1. Harga bersaing yakni membandingkan antara $\mathrm{t}$ hitung dengan $t$ tabel, maka dapat diketahui nilai $t$ hitung untuk variabel harga bersaing dengan nilai perrhitungan sebesar 5,468 lebih besar dari t tabel 2,009 ini membuktikan bahwa harga bersaing berpengaruh signifikan terhadap kepuasan konsumen property.

2. Kualitas pelayanan, yakni dengan nilai perhitungan sebesar 2,041 lebih besar dari t tabel 2,009 yang juga berarti bahwa kualitas pelayanan berpengaruh signifikan terhadap kepuasan konsumen.

Hasil uji secara simultan yakni dengan menggunakan uji $\mathrm{F}$ dimana $\mathrm{F}$ hitung sebesar 27,406 lebih besar dari $\mathrm{F}$ tabel 3,19 ini berarti Ho ditolak.

Tabel 4: Hasil Uji F (Simultan)

\begin{tabular}{|l|l|r|r|r|r|r|}
\hline \multicolumn{2}{|l|}{ Model } & $\begin{array}{c}\text { Sum of } \\
\text { Squares }\end{array}$ & df & Mean Square & F & Sig. \\
\hline 1 & Regression & 3723.700 & 2 & 1861.850 & 27.406 & $.000^{\mathrm{a}}$ \\
\cline { 2 - 7 } & Residual & 3328.820 & 49 & 67.935 & & \\
\cline { 2 - 7 } & Total & 7052.519 & 51 & & & \\
\hline
\end{tabular}

Kemudian dari hasil perhitungan koefesien determinasi (Ajusted R Square) diperoleh nilai sebesar 0,509. Hal ini menunjukkan bahwa harga dan kualitas pelayanan memberikan pengaruh sebesar 50,9\% terhadap kepuasan pada konsumen perumahan PT. Atlantik Perkasa Abadi Pekanbaru. Sisanya 49,1\% merupakan variabel lain yang tidak termasuk dalam penelitian.

\section{Membangun Kepuasan Konsumen Melalui Harga Bersaing}

Harga berpengaruh dan signifikan terhadap kepuasan konsumen perumahan di PT. Atlantik Perkasa Abadi 
Jurnal Ilmiah Ekonomi dan Bísnis

Vol. 16. No.2, September 2019: 135-142

EISSN : $2442-9813$

ISSN : $1829-9822$

Pekanbaru. Hal ini sejalan dengan pendapat dengan pendapat Juwandi (2008:37) yang menyatakan bahwa salah satu faktor pendukung kepuasan pelanggan adalah harga. Untuk pelanggan yang sensitif, harga murah adalah sumber kepuasan yang penting karena pelanggan akan mendapatkan value of money yang tinggi.

Hasil ini mendukung pendapat Moch. Gozali (2014) bahwa faktor harga bersaing turut mendorong meningkatkan kepuasan konsuemn.

\section{Membanun Kepuasan Konsumen Melalui Kualitas Pelayanan}

Kualitas pelayanan berpengaruh dan signifikan terhadap kepuasan konsumen di perumahan PT. Atlantik Perkasa Abadi Pekanbaru. Hal ini sejalan dengan pendapat dengan pendapat Kotler (dalam Lupiyoadi, 2006:192), yang mengatakan bahwa kepuasan merupakan tingkat perasaan dimana sesorang perbandingan atas kinerja produk (jasa) yang diterima dan yang diharapkan. Hal ini mendukung pendapat Zeithamal dalam Lupiyoadi (2006)), faktor utama penentu kepuasan pelanggan adalah persepsi pelanggan terhadap kualitas jasa.

\section{Membangun Kepuasan Konsumen Melalui Harga Bersaing dan Kualitas Pelayanan}

Harga dan kualitas pelayanan secara bersama-sama berpengaruh dan signifikan terhadap kepuasan konsumen di perumahan PT. Atlantik Perkasa Abadi Pekanbaru. Hal ini sejalan dengan pendapat Daryanto (2014) yang mengatakan bahwa harga dan kualitas pelayanan merupakan faktor yang mempengaruhi kepuasan pada konsumen.

Hal ini juga sejalan dengan hasil penelitian Ade Syarif Maulana (2016), yang mengatkan bahwa kualitas pelayanan dan harga bersama-sama berpengaruh terhadap kepuasan pelanggan.

\section{KESIMPULAN DAN SARAN}

Kesimpulannya antara lain bahwa harga bersaing dan juga kualitas pelayanan berpengaruh siginifikan terhadap variabel $\mathrm{Y}$ dan kemudian secara bersama-sama juga pengaruhnya signifikan. Dari kedua variabel tersebut, dapat diketahui variabel harga bersaing lebih besar pengaruhnya bila dibandingkan dengan kualitas pelayanan. Artinya bahwa konsumen dalam membeli property lebih mempertimbangkan harga dibandingkan layanan.

Jadi diharapkan kepada produsen perumahan dalam rangka meningkatkan penjualan perumahan perlu memperhatikan kepuasan konsumen melalui penerapan kebijakan harga yang bersaing.

\section{DAFTAR PUSTAKA}

Abdullah, Thamrin., dan Francis Tantri. 2014. Manajemen Pemasaran. Jakarta : PT. RajaGrafindo Persada.

Alma, Buchhari. 2009. Pengantar Bisnis. Bandung : Alfabeta.

Amanah, Dita. 2010. Pengaruh Harga dan Kualitas Produk Terhadap Kepuasan Konsumen pada Majestyk Bakery \& Cake Shop Cabang H.M Yamin Medan. Jurnal Keuangan \& Bisnis. Volume 2, Nomor 1, Maret.

Bilgies. 2016. sPeran kualitas produk, harga dan kualitas layanan terhadap kepuasan pelanggan Billagio Skincare Clinic Sidoarjo. Jurnal Ekonomi Universitas kediri. Volume 1, Nomor 1, April.

Daryanto, Ismanto Setiabudi. 2014. Konsumen dan Pelayanan Prima. Malang : Gaya Media. 
Jurnal Ilmiah Ekonomí dan Bísnis

Vol. 16. No. 2, September 2019: 135-142 EISSN : $2442-9813$ ISSN : $1829-9822$

Faradina, Anissa., dan Budhi Satrio. 2016.

Pengaruh Promosi dan Kualitas

Pelayanan terhadap Kepuasan

Pelanggan pada Rumah Cantik

Alamanda. Jurnal Ilmi Riset dan

Manajemen. Volume 5, Nomor 7, Juli.

Ghozali, Moch. 2014. Pengaruh Kualitas Pelayanan dan Harga Terhadap Kepuasan Pelanggan pada Ekspedisi di Surabaya. Jurnal Ilmu Riset Manajemen. Volume 3, Nomor 3.

Haily dan Sri Yanti. 2016. Pengaruh Kualitas Pelayanan, Harga dan Promosi terhadap Kepuasan Konsumen pada PT. Prima Tour And Travel. Jurnal. Volume 8, Nomor 2, Oktober.

Hasibuan, Putri Handayani. 2016. Analisis Pengaruh Kualitas Pelayanan, Harga dan Lokasi terhadap Kepuasan Pengguna Jasa Damri di Bandara Soekarno Hatta (Studi Kasus Terhadap Pengguna Jasa Damri Bandara Soekarno-Hatta). Skripsi. Vakultas Ekonomi dan Bisnis, Universitas Islam Negeri Syarif Hidayatullah.

Hosang, Natasja, Altje Tumbel dan S Moniharapon. 2016. Analisis Pengaruh Kualitas Pelayanan dan Harga Terhadap Kepuasan Pasien (Studi Kasus pada Rumah Sakit Siloam Manado). Jurnal Berkala Ilmiah Efisiensi. Volume 16. Nomor 1.

Juwandi, Hendy Irawan. 2008. Kepuasan Pelayanan Jasa. Jakarta: Salemba Empat.

Kotler, Philip dan Keller. 2012. Manajemen Pemasaran. Jakarta : PT. Index.
Lupiyoadi, Rambat. 2006. Manajemen Pemasaran Jasa. Jakarta : Salemba Empat.

Malau, Harman. 2017. Manajemen Pemasaran Teori dan Aplikasi Pemasaran Era Tradisional Sampai era Modernisasi Global. Bandung: Alfabeta

Maulana, Ade Syarif. 2010. Pengaruh Kualitas Pelayanan dan Harga Terhadap Kepuasan Pelanggan PT. TOI. Jurnal Ekonomi. Volume 7, Nomor 2, November.

Nyoto. 2015. Metodologi Penelitian Teori dan Aplikasi. Pekanbaru : Badan Penerbit Universitas Riau.

Panjaitan, Ingrid. (2016). Pengaruh Pelayanan Dan Harga Pada Go-Jek Terhadap Kepuasan Konsumen Dengan Minat Sebagai Variabel Moderating. Jurnal. Volume 19, Nomor 2, Juli.

Pelealu, Vionita Rosaliana., Silvya Mandey dan Rotinsulu Jopie Jone (2016). Analisis Strategi Promosi dan Kualitas Pelayanan Terhadap Kepuasan Pengguna Car Care Center (C3) Car Wash Manado. Jurnal EMBA. Volume 4, Nomor 2, Juni.

Permadi, Rangga Wicaksono. 2011. Analisis Pengaruh Harga dan Pelayanan Terhadap Kepuasan Pelanggan Speedy di Jakarta Pusat. Tugas Akhir. Telkom University

Sangadji, Etta Mamang, dan Sopiah. 2013. Prilaku Konsumen, Pendekatan Praktis. Yogyakarta : Penerbut Andi. 
Jurnal Ilmiah Ekonomi dan Bísnis

Vol. 16. No.2, September 2019: 135-142

EISSN : $2442-9813$

ISSN : $1829-9822$

Suhendi dan Indra Sasangka. 2014. Pengantar Bisnis. Bandung : Alfabeta.

Sugiyono. 2012. Metode Penelitian Kuantitatif, Kualitatif dan $R \& D$. Bandung : Alfabeta.

Sugiyono. (2010). Statistika untuk Peneliian. Bandung: Alfabeta.

Swasta, Bashu dan Ibnu Sukotjo. 2010. Pengantar Bisnis. Yogyakarta : Liberti.

Tjiptono, Fandy. 2008. Strategi Pemasaran. Yogyakarta : Penerbut Andi.

Tjiptono, Fandy. 2014. Pemasaran Jasa. Yogyakarta : Penerbut Andi.

Tjiptono, Fandy. 2014. Pemasaran jasaprinsip, penetapan dan penelitian. Yogyakarta : Penerbut Andi.

Tjiptono, Fandy dan Gregorius Chandra. 2011. Service, Quality \& Satisfaction. Yogyakarta : Penerbut Andi.

Tjiptono, Fandy dan Gregorius Chandra. 2012. Pemasaran Strategik. Yogyakarta: Penerbut Andi.

Tjiptono, Fandy dan Anastasia Diana. 2016. Pemasaran Esensi dan Aplikasi. Yogyakarta : Penerbut Andi.

Umar, Husein. 2005. Riset Pemasaran dan Prilaku Konsumen. Jakarta : PT. Gramedia Pustaka Utama.
Wijaya, Tony. 2011. Manajemen Kualitas Jasa: Desain Servqual, QFD, dan Kano: Diesrtai Contoh Aplikasi dalam Kasus Penelitian. Jakarat: PT. Index. 